\title{
Feature inheritance versus extended projections ${ }^{*}$ Hans Broekhuis Version 2.5, September 2015
}

\begin{abstract}
This article shows that the empirical data that Chomsky (2008) provides in favor of feature inheritance and parallel movement are rather suspect, and that there are both empirical and conceptual reasons to reject this implementation of the idea that the formal features in $\mathrm{C}$ and $\mathrm{T}$ originate in a single head position. This does not imply, however, that the latter idea should be completely rejected. This paper argues that there are also reasons to assume that the relevant features all originate in the T-head, and that the C-position comes (or rather: may come) into existence as a result of the remerge of $\mathrm{T}$ as a specific instantiation of the formation of extended projections in the sense of Grimshaw (1997). We will conclude by showing that the extended projection approach is preferred to the feature inheritance approach in terms of optimization/economy given that for subject-initial sentences, CP-structures are normally harmonically bounded by TP-structures due to the fact that they invoke additional violations of *MOVE and *MERGE.
\end{abstract}

Keywords: feature inheritance, parallel movement, extended projections, subject-island condition, do-support, complementizer-trace effect, weak pronouns, wat voor-split, transitive expletive construction, multiple specifiers, phonological readjustment rules, full interpretation, legibility conditions, bare output conditions, optimization.

\section{Introduction}

Den Besten (1983: appendix II) proposed that "complementizer attraction transformations" are all of the type in (1). This predecessor of the Last Resort approach to movement currently found in the minimalist framework was not only proposed for the various forms of whmovement (including topicalization, relativization, and left-dislocation), but was extended to verb-second on the assumption that the complementizer position contains (in current terms) morphosyntactic tense $/ \varphi$-features that match the tense $/ \varphi$-features on the finite verb.

$\begin{array}{ccccc}X & -\left[+\mathrm{F}_{\mathrm{i}}\right] & -\mathrm{Y} & -\left[\mathrm{C}+\mathrm{F}_{\mathrm{i}}\right] & -\mathrm{Z} \\ 1 & 2 & 3 & 4 & 5 \\ 1 & 4 & 3 & \mathrm{e} & 5\end{array}$

where (i) $\mathrm{C}$ is some constituent, and (ii) $\mathrm{F}_{\mathrm{i}}$ is some morphosyntactic feature.

Den Besten argues that the postulation of tense/ $\varphi$-features in complementizer position is not only motivated by verb-second, but receives additional support from the fact that the form of complementizers at least partly depends on the finiteness of their clause (cf. the contrast between English that/if and for) as well as the fact that in certain languages complementizers

\footnotetext{
*Affiliation: Meertens Institute, Amsterdam. Email: hans.Broekhuis@meertens.knaw.nl. Section 2 is a revised version of Broekhuis (2005). I like to thank Marcel den Dikken for comments on an earlier version of this paper and for providing me with some clarifications to his 2012-manuscript discussed in Section 3.2, and the reviewers and editors of this volume for various suggestions that helped me to improve the exposition.
} 
and finite verbs are both able to agree with the subject; see, e.g., Zwart (1997) for a brief review of complementizer agreement in the Germanic languages, and references.

The claim that that the complementizer position (henceforth: $C$ ) contains a tense feature is somewhat problematic within the principles-and-parameters framework in view of the postulation of a separate inflectional/tense head (henceforth: $\mathrm{T}$ ) besides $\mathrm{C}$, which seems needed in order to create separate positions for, respectively, the subject of the clause and whmoved phrases. Under more or less standard assumptions within the principles-andparameters framework, a wh-construction like What did Bill see? would have the structure in (2), where I omitted the intermediate trace/copy of the wh-phrase that is predicted to arise when one adopts Barrier Theory (Chomsky 1986) or the Phase Impenetrability Condition (Chomsky 2000/2001) — since nothing in what follows crucially hinges on such intermediate traces, I will continue to do so in the remainder of this article.

$$
\text { [CP Op } \left.\mathrm{j}_{\mathrm{j}} \mathrm{C}\left[\mathrm{TP} \text { Subject }_{\mathrm{i}} \mathrm{T}\left[{ }_{\mathrm{vP}} t_{\mathrm{i}} v\left[\mathrm{vP} \mathrm{V} t_{\mathrm{j}}\right]\right]\right]\right]
$$

Since the assignment of nominative case to the subject is closely related to finiteness, it seems reasonable to assign the tense features not to $\mathrm{C}$, but to $\mathrm{T}$. However, the fact that, according to the Head Movement Constraint, the finite verb in verb-second constructions cannot be moved into $\mathrm{C}$ in one fell swoop but must be moved via the intermediate $\mathrm{T}$-position still suggests that there is a feature match between $\mathrm{C}, \mathrm{T}$, and $\mathrm{V} .{ }^{1}$ Given this, it need not surprise us that Den Besten's proposal that C may contain a tense (or finiteness) feature has been a constant within generative grammar since the mid-1980s; see, e.g., the contributions in Haider \& Prinzhorn (1989), Holmberg \& Platzack (1995), and Pesetsky \& Torrego (2001).

The currently best-known incarnation of this claim is probably the postulate of feature inheritance in Chomsky (2008:143-4). He proposes that the tense/ $\varphi$-features all originate in $\mathrm{C}$ and that $\mathrm{T}$ receives these features from $\mathrm{C}$ by inheritance. His proposal is summarized in (3a).

(3) a. C and $v^{*}$, but not $\mathrm{T}$ or $\mathrm{V}$, are phase heads.

b. Feature-inheritance theory: phase heads have both edge and unvalued formal features and thus trigger both $\mathrm{A}^{\prime}$ - and A-movement; unvalued formal features are inherited by the non-phase heads that the phase heads select.

c. Parallel movement: syntactic operations triggered by the edge and unvalued formal features proceed in parallel at the end of the phase, that is, $\mathrm{A}^{\prime}$ - and A-movement proceed simultaneously.

This article will show, however, that the empirical data that Chomsky provides in favor of feature inheritance and parallel movement are rather suspect, and that there are both empirical and conceptual reasons to reject this implementation of the idea that the features in $\mathrm{C}$ and $\mathrm{T}$ originate in a single head position. This does not imply, however, that the idea as such should be completely rejected-I will show that an approach of this sort is possible when we assume that the relevant features all originate in the T-head, and that the C-position comes (or rather, may come) into existence as a result of remerge of this head as a specific instantiation of the formation of extended projections in the sense of Grimshaw (1997); see also Ackema, Neeleman \& Weerman (1992) and Nash \& Rouveret (1997) for similar ideas. This paper

\footnotetext{
${ }^{1}$ Of course, this presupposes that verb/head movement is a syntactic operation, contrary to what is assumed in Chomsky (2001:37) on the basis of the claim that the "semantic effects of head movement are slight or nonexistent". Apart from the fact that this claim is false (compare the difference between John will go home versus Will John go home?), Chomsky's claim that verb raising is a phonological operation is incompatible with his earlier claim in the same paper that object shift must be a syntactic operation. Since object shift cannot apply across a verb in VP-internal position, verb raising must precede object shift. Consequently, if object shift is a syntactic operation, verb raising must also be a syntactic operation. See Broekhuis (2008) for more discussion.
} 
compares some empirical and theoretical consequences of the feature inheritance (FI) and extended projection (EP) approach, and concludes that the latter is superior on both counts.

The discussion is organized as follows. Section 2 will start with a critical review of Chomsky's empirical motivation of feature inheritance and, especially, the concomitant claim that A- and $\mathrm{A}^{\prime}$-movement proceed in a parallel fashion. Section 3 discusses the conceptual motivation of the FI-approach, and will show that these are all highly theory-internal, and what is probably worse, at least mildly regressive in the sense that it is based on theoretical constructs that are in need of an empirical motivation themselves. Section 4 will show that the EP-approach can be more straightforwardly motivated by a number of well-known empirical facts, which do not receive a natural account under the FI-approach, and that this approach is therefore to be preferred. Section 5 concludes the discussion with a conceptual argument in favor of the EP-approach based on the distinction between A- and $\mathrm{A}^{\prime}$-movement.

\section{Parallel movement}

Chomsky (2008) claims that extraction from subject is possible when the subject is an internal argument (henceforth: derived subject), but not when it is an external argument (henceforth: underlying subject): in short, subject islands are invoked by underlying subjects only. This empirical claim is then employed to support the three theoretical proposals in (3). Claim (3a) is familiar from Chomsky's earlier work and can in part be traced back to barrier theory, first outlined in Chomsky (1986). Claim (3b) amounts to saying that the $\varphi$-features on $\mathrm{T}$ and $\mathrm{V}$ are inherited from $\mathrm{C}$ and $v^{*}$ (the light verb associated with verbs that take an external argument) respectively; the fact that $\mathrm{T}$ and $\mathrm{V}$ do not inherently contain $\varphi$-features is given as a motivation for the claim in (3a) that these heads do not define phases. Claim (3c), finally, states that $\mathrm{A}^{\prime}$-movement does not attract the head of an A-chain, as was assumed in earlier proposals, but the foot - if a phase head contains features that trigger A- and $\mathrm{A}^{\prime}$-movement, these movements must proceed in parallel. The derivation in (4) illustrates the consequences of the theoretical claims in $(3 \mathrm{~b} \& \mathrm{c})$ for the derivation of an interrogative clause with a wh-object; $T$ attracts the subject DP by virtue of inheriting the $\varphi$-features of $C$, and the object simultaneously moves in order to check the [Q]-feature on $\mathrm{C}^{2}$

Wh-object questions in the FI-approach:

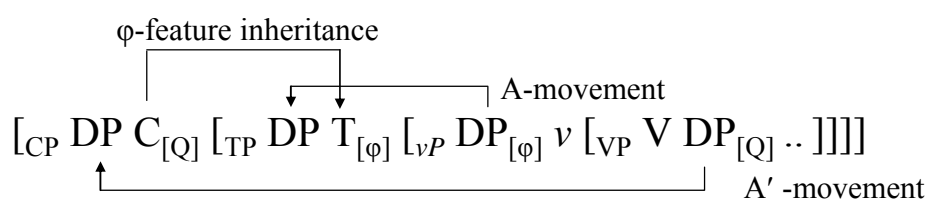

This section investigates the empirical support for the proposals in ( $3 b \& c)$, and is organized as follows. Section 2.1 briefly reviews Chomsky's empirical claim that wh-extraction is possible from derived but not underlying subjects, and shows how the proposals in (3b\&c) follow from this. Section 2.2 then continues to argue that the examples used in support of the empirical claim concerning wh-extraction from subject are suspect, and Section 2.3 will provide a straightforward counterexample to it. I will conclude from the discussion in Sections 2.1 to 2.3 that the theoretical proposals in (3b\&c) are still in need of independent

\footnotetext{
${ }^{2}$ Recall that I will omit from the representation the intermediate trace/copy of the wh-phrase that is predicted to arise when we adopt the Phase Impenetrability Condition. An alternative for assuming that wh-movement is licensed by a morphosyntactic [Q]-feature is to assume that the movement is semantically motivated by the need to create an operator-variable chain. This option seems incompatible with the FI-approach but can readily be formulated in the alternative EP-approach. I will return to this in Section 5.
} 
motivation. ${ }^{3}$ Section 2.4 explicitly argues against assumption $(3 \mathrm{c})$ by showing that there are strong arguments against assuming parallel movement, that is, derivations of the sort in (4).

\subsection{Extraction from subject}

Chomsky (2008) claims that the traditional formulation of the subject-island condition is too strict, and that it should be construed such that it prohibits movement from underlying subjects (external arguments) only. He provides the (a)- and (b)-examples in (5) to show that extraction from a derived subject (internal argument) is as acceptable as extraction from a direct object; the unacceptability of the (c)-examples, on the other hand, is taken to show that extraction from an underlying subject is blocked.

(5) a. It was the CAR (not the TRUCK) of which $\mathrm{i}_{\mathrm{i}}$ they found [DP the driver $t_{\mathrm{i}}$ ].

$\mathrm{a}^{\prime}$. Of which car ${ }_{\mathrm{i}}$ did they find [DP the driver $\left.t_{\mathrm{i}}\right]$ ?

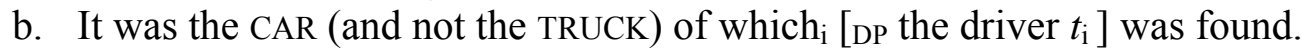

$\mathrm{b}^{\prime}$. Of which car $\mathrm{i}_{\mathrm{i}}$ was [DP the driver $t_{\mathrm{i}}$ ] awarded a prize?

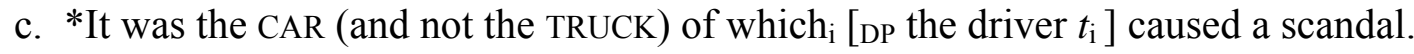

$\mathrm{c}^{\prime} .{ }^{*}$ Of which car $_{\mathrm{i}}$ did [DP the driver $t_{\mathrm{i}}$ ] cause a scandal?

Chomsky proposes the following derivations. Extraction of the PP from the object DP in the transitive (a)-examples in (5) is assumed to proceed in the by now familiar fashion: the PP is first attracted by an edge- or EPP- (henceforth: EPP) feature on $v^{*}$, as a result of which it is at the edge of the $v^{*} \mathrm{P}$ phase; subsequently, it can be attracted by the next higher phase head $\mathrm{C}$ into SpecCP. Extraction from the subject in the passive (b)-examples in (5) is claimed to proceed in more or less the same way, although it might be that the PP is moved into SpecCP in one fell swoop because Chomsky assumes that the light verb $v$ associated with passive and unaccusative verbs is not a phase head and therefore does not define a phase boundary. It is not so clear what causes the deviance of the extraction of the PP from the subject DP in the transitive (c)-examples in (5); the external argument is at the edge of the $v^{*} \mathrm{P}$ phase, and should therefore be accessible for the next higher phase head C. Chomsky suggests, however, that $\mathrm{C}$ cannot attract the PP, because the latter is too deeply embedded in a phase already passed in the derivation; see Chomsky $(2008: 147-8,154)$. For the sake of the argument, let us assume that this indeed suffices to make the right distinction (although it doesn't seem to follow from any of the independently motivated constraints on movement).

It is crucial that extraction of the PPs from the subjects in the (b)- and (c)-examples does not apply from SpecTP. If that were the case, no distinction could be made between the (b)- and the (c)-examples in (5): these examples would then all have the derivation in (6a), in which the PP is extracted from a DP in SpecTP, so that they would be expected to have the same grammaticality status. Instead, extraction of the PP should take place from the subject in its base position, as in (6b), so that the movement can be made sensitive to the question whether the subject occupies Spec $v * P$ or a VP-internal position.

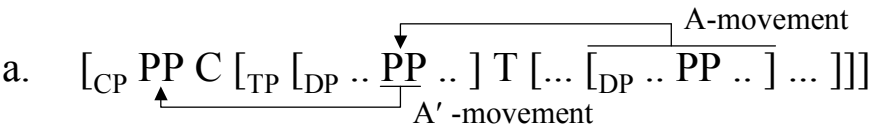

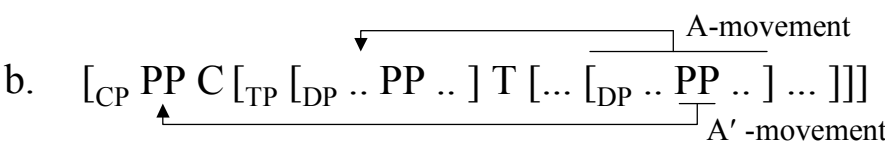

\footnotetext{
${ }^{3}$ There are a number of proposals available that aim at providing such independent motivation, but I will postpone the discussion of these to Sections 3 and 4 for reasons of exposition. This section is strictly confined to a discussion of the subject-island condition.
} 
The claims in (3b\&c) are intended to block the derivation in (6a) in favor of the one in (6b). Assumption (3c), according to which the A- and $\mathrm{A}^{\prime}$-movements triggered by a phase head (here: C) proceed in parallel, straightforwardly forces the derivation to proceed as in (6b): at the moment that $\mathrm{A}^{\prime}$-movement applies, the subject still occupies its base position. Assumption ( $3 \mathrm{~b}$ ) is also needed, because if we assume that $\mathrm{T}$ has $\varphi$-features independent of $\mathrm{C},(3 \mathrm{c})$ would not be applicable and A-movement would still precede $\mathrm{A}^{\prime}$-movement, as in (6a). Finally, assumption (3a) is needed, because if T were a phase head, TP would be a phase and the PP would be "too deeply embedded in a phase already passed in the derivation" in all examples in (5), so that they would all be predicted to be ungrammatical.

\subsection{Extraction from subject?}

This subsection will argue that the examples in (5) do not support Chomsky's empirical claim that wh-extraction is possible from derived (but not underlying) subjects. For my own convenience, I will use Dutch examples to illustrate matters. First, it must be noted that constructions like (5) are of a very restricted sort in the sense that the allegedly extracted PP can only be headed by a limited set of prepositions. In Dutch this set is exhausted by van 'of' and over 'about'; PPs headed by, e.g., clearly locational prepositions are never extracted from DP. This is illustrated in (7) for extraction from object; (7b) is acceptable when the PP is construed as a locational adverbial phrase but not on its intended reading as a modifier of the noun huis 'house'. Chomsky's proposal, however, wrongly predicts the latter reading to be possible.

(7) a. Jan heeft het huis op de hoek gekocht.

Jan has the house on the corner bought

'Jan has bought the house on the corner.'

b. *Op de hoek heeft Jan [DP het huis $t_{\mathrm{i}}$ ] gekocht.

Secondly, it is not so clear whether the van-PP in examples like (8a) is really extracted from the object; under the right contextual and pragmatic conditions the object-DP de eigenaar 'the owner' can be replaced by a pronoun. Since pronouns normally resist modification, this suggests that the preposed van-PP does not function as a complement or a modifier of the noun, but rather as an independent adverbial phrase. Note in passing that the preposed van-PP in (8) triggers a contrastive reading, and that apparently the same holds for the primeless examples in (5), given Chomsky's use of small caps and the addition of a contrastive phrase.

(8) a. Van DEZE auto hebben ze de eigenaar nog niet gevonden (van DIE wel) of this car have they the owner not yet found of that.one AFF

b. Van DEZE auto hebben ze hem nog niet gevonden (van DIE wel).

From this car have they him not yet found. of that.one AFF

A final piece of evidence in favor of the claim that the preposed van-PP is an independent adverbial phrase is that the preposed van- $P P$ can be modified by a focus particle, whereas a postnominal van-PP cannot; if the preposed van-PP in (9a) originates from within the object DP, the ungrammaticality of (9b) would be surprising. I refer the reader to Broekhuis \& Keizer (2012:156ff.) for a more detailed discussion.

(9) a. Alleen van deze auto hebben ze de eigenaar nog niet gevonden. only of this car have they the owner not yet found

b. *Ze hebben de eigenaar alleen van deze auto nog niet gevonden. they have the owner only of this car not yet found 
This section has given three arguments against an analysis according to which the preposed PPs in (5) are extracted from the object-DP, and argued that these PPs are generated as independent adverbial phrases. Suppose, however, that one could successfully argue that the Dutch data in (7) to (9) can be accommodated under an extraction-from-DP analysis. Even then, I think, Chomsky's claim that extraction is only possible from derived subjects cannot be maintained, because it is actually quite simple to construct examples like (10), for which one might then claim that a van-PP is extracted from an underlying subject, and which would thus show that the alleged contrast between derived and underlying subjects does not hold generally.

(10) a. Van DEZE fabriek hebben de werknemers gisteren het werk onderbroken. of this factory have the employees yesterday the work interrupted 'Of this factory, the employees interrupted their work yesterday.'

b. Van DEZE school hebben alle leerlingen verleden jaar de marathon gelopen. of this school have all the pupils last year the marathon run 'Of this school, all the pupils ran the marathon last year.'

\subsection{Extraction from subject!}

The previous subsection argued that Chomsky's alleged cases of PP-extraction from object/subject actually involve cases in which the PP functions as an independent adverbial phrase. This section will discuss a case that traditionally has been analyzed as involving extraction from argument, the so-called wat voor-split. We will see that this split does not lend support to Chomsky's claim that extraction is possible from derived subjects only: extraction of wat is equally (im)possible from derived and from underlying subjects. At first sight, this claim is perhaps surprising, given that Den Besten (1985) has contended that the wat voor-split is possible with direct objects and derived subjects $\left(11 \mathrm{a}^{\prime} \& \mathrm{~b}^{\prime}\right)$, but not with underlying subjects $\left(11 \mathrm{c}^{\prime}\right)$.

(11) a. Wat voor romans heeft hij geschreven?

what for novels has he written

'What kind of novels has he written?'

$\mathrm{a}^{\prime}$. Wat heeft hij voor romans geschreven?

b. Wat voor rare verhalen zijn (er) jouw vader verteld?

what for strange stories are there your father told

'What kind of strange stories have been told to your father?'

$\mathrm{b}^{\prime}$. Wat zijn (er) jouw vader voor rare verhalen verteld?

c. Wat voor mensen hebben je moeder bezocht? what for people have your mother visited

'What sort of people have visited your mother?'

$\mathrm{c}^{\prime}$. *Wat hebben voor mensen je moeder bezocht?

Den Besten's examples in (11) therefore seem to support Chomsky's claim, but closer scrutiny quickly reveals that this is not really the case. The difference between $\left(11 b^{\prime}\right)$ and $\left(11 c^{\prime}\right)$ is not that the former involves a derived, whereas the latter involves an underlying subject, but is related to the position of the stranded part of the wat voor-phrase: in $\left(11 b^{\prime}\right)$ the stranded part is $v \mathrm{P}$-internal, which is shown by the fact that it follows the indirect object jouw vader 'your father', whereas in $\left(11 \mathrm{c}^{\prime}\right)$ the stranded part is in the regular subject position, SpecTP. That this is the crucial difference is clear from the fact that when the remnant of $\left(11 b^{\prime}\right)$ occupies SpecTP, as in $(12 a)$, the result is as unacceptable as $\left(11 c^{\prime}\right)$. And if the 
remnant of $\left(11 \mathrm{c}^{\prime}\right)$ is placed in $v \mathrm{P}$-internal position, as in the expletive er construction in $(12 \mathrm{~b})$, the result seems as acceptable as $\left(11 b^{\prime}\right){ }^{4}$

(12) a. *Wat zijn voor rare verhalen jouw vader verteld?

what are for strange stories your father told

b. Wat hebben er voor mensen je moeder bezocht?

what have there for people your mother visited

The conclusion we have to draw from the discussion above is that, contrary to Chomsky's claim, extraction from subject is equally (im)possible from derived and underlying subjects, and hence that the theoretical claims in (3b\&c) are not independently motivated. Observe that this conclusion is actually desirable for theoretical reasons, since, as was already noticed in Section 2.1, the ban on extraction from underlying subjects does not follow from any independently motivated condition on movement, and we therefore also expect the wat voorsplit to be possible from underlying subjects in $v \mathrm{P}$-internal position.

\subsection{A- and $\mathrm{A}^{\prime}$-movement do not proceed in parallel}

The fact that the theoretical proposals in (3b\&c) are not independently motivated does not necessarily mean that they are incorrect. However, the fact that the assumptions $(3 \mathrm{~b} \& \mathrm{c})$ are only needed to derive Chomsky's incorrect generalization on extraction from subject makes these assumptions highly suspect, so that they should be eliminated from the grammar.

For stipulation (3c) we can even do better than applying Ockham's razor by showing that it is simply false. For this, we only have to consider again the contrast between the primeless and primed examples in (13), which are repeated from (11) and (12).

(13) a. Wat zijn (er) jouw vader voor rare verhalen verteld?

what are there your father for strange stories told

$\mathrm{a}^{\prime}$. *Wat zijn voor rare verhalen jouw vader verteld?

b. Wat hebben er voor mensen je moeder bezocht? what have there for people your mother visited

$\mathrm{b}^{\prime}$. *Wat hebben voor mensen je moeder bezocht?

In the expletive constructions in $(13 \mathrm{a} \& \mathrm{~b})$, the remnant of the wat voor-phrase occupies a $\mathrm{vP} / v^{*} \mathrm{P}$-internal position, whereas in $\left(13 \mathrm{a}^{\prime} \& \mathrm{~b}^{\prime}\right)$ the remnant occupies the regular subject position. If the assumption in $(3 \mathrm{c})$ were correct, we would wrongly predict that the primed and primeless examples in (13) have an equal status, the only difference being that the Amovement in (14) does not apply in the primeless examples.

\footnotetext{
${ }^{4}$ I use the verb seem here because Den Besten actually claims that wat voor-split gives rise to a marked result in expletive constructions with an intransitive verb. So Den Besten assigns "?*" to example (ia). I do not agree with his judgment; to my ear, this example is fully acceptable. Furthermore, there is a very sharp contrast between the expletive construction in (ia), which we may assume to involve a subject in vP-internal position, and example (ib), in which the subject resides in SpecTP. Broekhuis (1991/1992) provides fully acceptable examples involving wat voor-split of subjects of transitive verbs; see De Hoop (1992: section 2.5) and Zwart (2011:212) for similar judgments as reported there.
}

(i) a. Wat hebben er eigenlijk voor mensen geprotesteerd?

what have there actually for people protested

'What kind of people actually protested?'

b. *Wat hebben voor mensen eigenlijk geprotesteerd? 


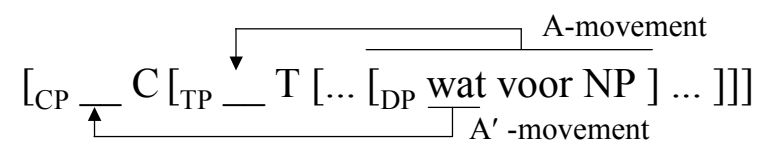

If movement of wat applies from the head of the A-chain, however, the desired distinction can be made: in the primeless examples in (13), movement of the subject into SpecTP does not apply so that extraction of wat takes place from the vP-internal position of the subject, as in (15a); in the primed examples, on the other hand, extraction of wat is preceded by Amovement of the subject, so that it takes place from SpecTP, as in (15b).

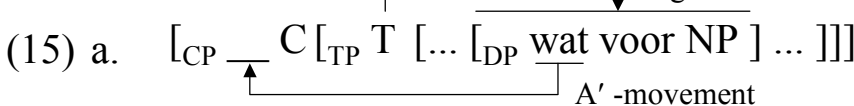

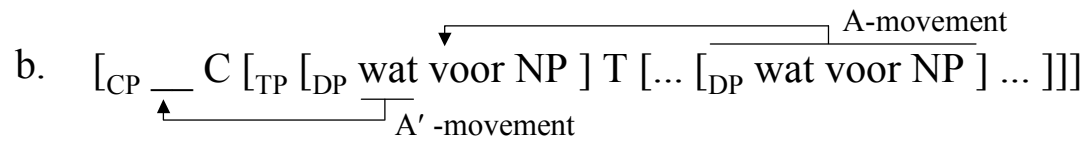

Thus, what we see in (13) is simply the effect of the traditional subject-island condition; we therefore have to conclude that stipulation (3c) cannot be part of the grammar. Of course, we still have to find a good minimalist account for the subject-island condition. I refer the reader to Chomsky (1995:328) for an attempt to account for the ungrammatically of example (16).

*Who was [a picture of _] taken by Bill.

Observe that the unacceptability of examples like (16) provides independent support for the conclusion I arrived at in this section, given that such examples are expected to be possible under the FI-approach; see also Den Dikken \& Van Craenenbroeck (2006:fn.1), who likewise suggest that Chomsky's examples in (5) "are amenable to an analysis not implicating subextraction from NP at all”.

\section{Feature inheritance}

Section 2 has shown that the subject-island condition in its traditional formulation is essentially correct, and that there is therefore little reason to assume that parallel movement is possible - in fact, the postulation of parallel movement has been shown to be undesirable on empirical grounds. Although this shows that the empirical underpinning of feature inheritance is quite feeble, it seems less easy to show on independent empirical grounds that postulating feature inheritance is undesirable: Section 3.1 will provide one potential empirical problem that is based on Kayne's (1994) universal base hypothesis, according to which all languages are SVO underlyingly, but this argument will probably only appeal to readers that do accept this hypothesis. I will therefore not digress on this issue long but take a different route in Section 3.2 by showing that there are serious conceptual problems with postulating a mechanism of feature inheritance.

\subsection{An empirical problem: the derivation of OV-structure}

When we assume that Kayne's (1994) universal base hypothesis, according to which all languages are SVO underlyingly, is essentially correct, we can build a case against the postulation of feature inheritance. According to this hypothesis, the surface OV-order of languages like Dutch is derived from an underlying VO-order by means of leftward movement of the internal argument across the verbal root V. In Broekhuis (2008) and earlier work, I argued that this movement is triggered by the $\varphi$-features on the verbal root $\mathrm{V}$. If $\mathrm{V}$ can only inherit such features from a phase head, we expect that in passive constructions $\mathrm{V}$ 
does not have these features, given that the light verb $v$ that we find in such constructions is generally assumed not to be a phase head. Now consider the Dutch passive examples in (17). ${ }^{5}$

(17) a. Morgen worden die boeken mijn oom $_{\mathrm{IO}}$ toegestuurd.

tomorrow be those book my uncle prt.-sent

'The books will be sent to my uncle tomorrow.'

b. Morgen worden mijn oom $\mathrm{IO}$ die boeken S $_{\mathrm{S}}$ toegestuurd.

c. *Morgen worden mijn oom IO $_{\text {toegestuurd die boeken }}$.

In (17a) the derived subject is simply moved into SpecTP; this option is expected under the assumptions in (3) and I have nothing special to say about this case in the present context. The crucial examples are given in (17b\&c); example (17b) shows that the derived subject can follow the indirect object, which suggests that it may occupy a $v \mathrm{P}$-internal position; example (17c) shows that the subject cannot occupy its base position to the right of $\mathrm{V}$, but must be moved leftwards. If the $\varphi$-features of $\mathrm{V}$ are indeed responsible for this movement, we must conclude that $\mathrm{V}$ has $\varphi$-features in passive constructions. This is excluded, however, by $(3 \mathrm{a} \& \mathrm{~b})$, given that the light verb $v$ in passive constructions is not a phase head. Consequently, (3b) cannot be correct and we have to assume that the $\varphi$-features are intrinsically part of $\mathrm{V}$ (and, by extension, also of T).

\subsection{Conceptual problems}

This section will argue that there is a serious conceptual problem with postulating feature inheritance. Chomsky (2008: 143-4) suggests that $\mathrm{T}$ is essentially featureless and that both the $\varphi$ - and the tense-features are inherited from C. The actual label of the inherited feature(s) is, of course, of minor importance, given that finiteness, subject-verb agreement, and nominative case assignment are all intimately related; see, e.g., Chomsky's (2001:6) proposal that structural case is a manifestation of agreement, and Pesetsky \& Torrego's (2001:362) hypothesis that nominative case is actually a manifestation of a tense feature on the determiner. However, the claim that $\mathrm{T}$ is essentially featureless does raise the conceptual question "why should feature inheritance (an indeed T itself) exist at all" (Richards 2007). The review that follows will show that the answers given to this question so far are highly theory-internal and unsatisfactory.

Chomsky (2008:144) relates feature inheritance to the A-A'-distinction, mentioning that there is ample evidence that the distinction exists. This may be true but does not necessarily imply the existence between separate A- and A'-positions. Richards (2007:564-5), for example, claims that it is essentially sufficient to postulate two different types of features: AGREE-type features that trigger A-movement and EPP-type features that trigger $\mathrm{A}^{\prime}$ movement. Furthermore, he claims that the availability of multiple specifiers allows "a simpler and thus more optimal alternative for feature inheritance: both of C's features can be satisfied in situ on C" in, respectively, the outer and the inner specifier of CP.

Richards (2007:5646-9) himself claims that feature inheritance is motivated by Full Interpretation, more precisely, the need to eliminate uninterpretable features ( $\mathrm{uFs}$ ) before they reach the semantic component. Assuming that valued $\mathrm{uFs}$ are indistinguishable from interpretable features, he claims that the elimination of $\mathrm{uFs}$ is only possible when valuation and transfer (spell-out to PF) of uFs apply simultaneously. Consequently, given that projections of non-phase heads can only be transferred at the phase level, non-phase heads cannot have any uFs. His conclusion is therefore that feature inheritance is needed: uFs must

\footnotetext{
${ }^{5}$ Similar examples can be given with dyadic unaccusativity verbs, but for the sake of brevity, I will not illustrate this here; see Lenerz (1977), Koster (1978), Den Besten (1985), Broekhuis (1992/2008) and the references cited there for data and extensive discussion.
} 
spread from phase heads to non-phase heads (from C to T, $v^{*}$ to V, etc). Den Dikken (2012) sides against Richard's claim that valued uFs must be eliminated before they reach the semantic component by saying that "it is not at all obvious either that a representation containing valued $\varphi$-features of an inflected verb would wreak havoc for Full Interpretation", and furthermore argues that Richard's proposal runs into problem in root clauses.

In his turn, Den Dikken (2012) suggests that feature inheritance only makes sense when we assume that it applies to EPP-features. This leads him to the conclusion that feature inheritance is intrinsically related to the EPP in the traditional sense: it triggers A-movement of the subject into SpecTP. This, however, predicts that V2-languages like Dutch have obligatory movement of the subject into SpecTP, which is clearly false in view of the fact, illustrated earlier in (17), that the subject may follow the indirect object in Dutch. Den Dikken is further forced to assume that pro-drop languages have an optional EPP-feature and, consequently, optional feature inheritance in order to allow A-movement of non-pronominal subjects into SpecTP. ${ }^{6}$ As shown in Broekhuis' (2008) discussion of a similar proposal in Chomsky (2001) for Scandinavian object shift, such optional EPP-features can simply be eliminated by appealing directly to the information-structural condition that determines whether the movement is possible or not: instead of saying that some information-structural condition licenses an EPP-feature on $\mathrm{F}$, which forces a certain $\mathrm{A}^{\prime}$-movement to apply, one can then simply say that the information-structural condition itself forces the movement to apply, thus making the postulation of EPP-features unnecessary entirely.

The discussion above has shown, I believe, that the quest for a theory-internal motivation for feature inheritance is at least mildly regressive in the sense that the claim that is supposed to support feature inheritance is itself in need of further support: we need more evidence for the claim (i) that it is necessary to assume a distinction between $\mathrm{A}$ - and $\mathrm{A}^{\prime}$ positions next to A- and $\mathrm{A}^{\prime}$-movement; (ii) that the edge and the non-edge of a phrase must be spelled out separately in order to satisfy Full Interpretation; and (iii) that there are such things as (optional) EPP-features. I think that, in tandem with the feeble empirical support in favor of feature inheritance, this makes a strong case for considering an entirely different approach to the issue of feature sharing between $\mathrm{C}$ and $\mathrm{T}$.

\section{Extended projections}

An alternative implementation of the idea that the features in $\mathrm{C}$ and $\mathrm{T}$ originate in a single head position is to assume that $\mathrm{T}$ is the actual carrier of these features and that the " $\mathrm{C}$ "-head only arises in the course of the derivation as a result of remerge of T; see Ackema, Neeleman \& Weerman (1992), Grimshaw (1997), and Nash \& Rouveret (1997). The features on T indicated in (18) are the ones that trigger $\mathrm{A}$ - and $\mathrm{A}^{\prime}$-movement, but the crucial assumption is that the goals are moved into specifier positions of separate projections. A-movement targets the specifier position of a lower TP and $\mathrm{A}^{\prime}$-movement targets the specifier of an extended projection of TP that is created by means of remerge of $\mathrm{T}$ (and which is normally referred to as "CP"). An advantage of the derivation in (18) is that A- and A'-movement apply sequentially, and we thus may derive the subject-island condition in the traditional sense by postulating a freezing effect of some sort; see Broekhuis (2008: Section 2.3.2) for an informal formulation of freezing that would provide the desired results.

\footnotetext{
${ }^{6}$ It is important to emphasize that Den Dikken (2012) is actually playing the devil's advocate: "If EPP should turn out to be a fact of life, we could still get around the need for FI if ...." Den Dikken (p.c.) further informs me that he believes that EPP features are not at all involved in subject movement in languages like Dutch, given that this movement is conditioned by certain interpretative effects; see, e.g., Broekhuis (2007/2008) for a detailed discussion of this as well as the continuation in the main text. The argument against feature inheritance of EPP features in the main text simply points at what I believe to be the logical consequences of Den Dikken's specific implementation of this idea.
} 
Wh-object questions in the EP-approach:

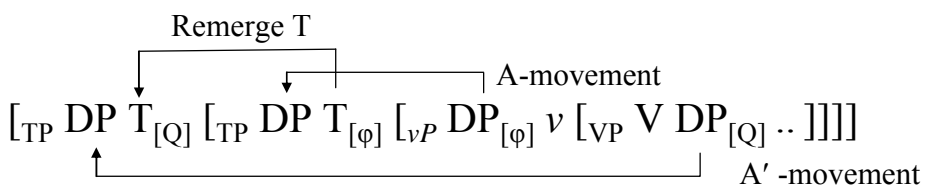

It is further important to note that the derivation in (18) is incompatible with the postulation of multiple specifiers; if multiple specifiers indeed exist, remerge of T would not be needed and hence be blocked by consideration of economy (compare Richard's objection to Chomsky's motivation for feature inheritance, discussed in Section 3.2). This immediately shows that the FI- and the EP-approach to feature sharing between $\mathrm{C}$ and $\mathrm{T}$ are not notational variants.

Since the option of having multiple specifiers seems to be generally accepted, I will start in Section 4.1 by briefly discussing the original motivation for introducing this option and by showing that the EP-approach, in fact, gives rise to a better empirical result. Section 4.2 continues by presenting additional empirical considerations.

\subsection{Transitive expletive constructions}

The idea that a head $\mathrm{H}$ is able to remerge in order to create additional landing sites for a second (or a third, etc.) goal is, of course, not possible within the version of the minimalist program as developed by Chomsky, where heads can have multiple specifiers. It may therefore be useful to go back to the original motivation for multiple specifiers, the Icelandic transitive expletive construction discussed by Jonas and Bobaljik (1993/1996).

$$
\begin{aligned}
& \text { pað borðuðu sennilega margir jólasveinar bjúgun. } \\
& \text { there ate probably many Christmas.trolls the.sausages } \\
& \text { 'Many Christmas trolls probably ate the sausages.' }
\end{aligned}
$$

Chomsky (1995:354) assumed that the subject and the expletive of such constructions are placed in, respectively, an outer and an inner specifier of TP, as depicted in (20a). A problem that arose for this proposal was that the resulting word order expletive-subject-verb is not the one found, so that we need an additional readjustment rule at PF in order to derive the desired verb-second order expletive-verb-subject.

$$
\text { [TP EXPL [subject V-T [vP } \mathrm{t}_{\text {subject }} \mathrm{t}_{\mathrm{v}} \text { object]]]. }
$$

This word order problem does not arise when we adopt the alternative EP-approach based on remerge of the head T, which may take the following shape; cf. Broekhuis (2000:fn7). First, the movement of the indefinite subject into SpecTP is triggered by the $\varphi$-features on $\mathrm{T}$. However, the indefinite subject can value only a subset of these features, given that it in NP and not a DP. Therefore, $\mathrm{T}$ must enter into an additional agreement relation with the expletive, which is a $\mathrm{D}$ by assumption. In order to create the required local relation between $\mathrm{T}$ and the expletive, $T$ remerges and the expletive is placed into the specifier of the extended projection thus created. The expletive and the subject must appear in the indicated order when we assume that the expletive $\mathrm{D}$ has an unvalued $\mathrm{N}$-feature that must be valued by the indefinite subject. This ensures that we derive the verb-second structure in (21) without the aid of a phonological readjustment rule.

$$
\text { [TP EXPL [V-T] [TP subject } t_{V-T}\left[{ }_{\text {vP }} t_{\text {subject }} t_{V}\right. \text { object]]] }
$$

An analysis of this sort seems simpler and is furthermore in accordance with our earlier conclusion in note 1 that verb movement is a syntactic rule. The fact that the Icelandic transitive expletive construction can be accounted for without appealing to a phonological 
readjustment rule within an EP-approach shows that it is worthwhile to further investigate the EP-approach to feature sharing between $\mathrm{T}$ and $\mathrm{C} .^{7}$

\subsection{Empirical considerations}

That the FI- and EP-approach to the idea that the features in $\mathrm{C}$ and $\mathrm{T}$ originate in a single head position are not notational variants is also clear from the fact that they give rise to entirely different results in the case of wh-subject questions like Who arrived? First, consider the structure in (22), which Chomsky (2008:149) assigns to such wh-subject questions. The derivation of such questions is similar to the derivation of wh-object questions in (4); the only difference is that in (22) A- and $\mathrm{A}^{\prime}$-movement probe the same phrase.

$$
\begin{aligned}
& \text { Wh-subject questions in the FI-approach: }
\end{aligned}
$$

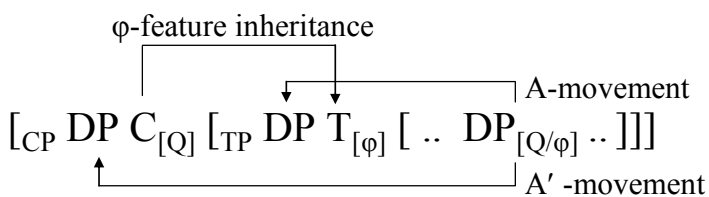

In the EP-approach, the derivation of wh-subject questions in (23) is entirely different from the derivation of wh-object questions in (18); since the subject can satisfy both the $\varphi$ - and the [Q]-feature on $\mathrm{T}$, there is no need to create an extended projection; economy considerations therefore block the creation of the extended "CP"-level. Note that under the EP-approach it suffices to distinguish between $\mathrm{A}$ - and $\mathrm{A}^{\prime}$-movement and there is no need to postulate a difference between A- and A'-positions; see also Richard's criticism on Chomsky (2008), reviewed in Section 3.2.

Wh-subject questions in the EP-approach:

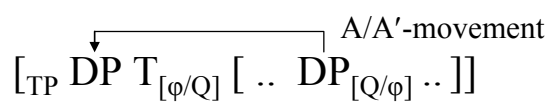

It seems that, more generally, the two approaches make different predictions concerning the "size" of finite clauses. According to the FI-approach, all main clauses have the same size; they are all CPs, given that $\mathrm{C}$ is the only bearer of unvalued formal features and $\mathrm{T}$ can only be endowed with them as the result of inheritance. The EP-approach, on the other hand, predicts that "CPs" (extra TP-layers) are only present when this is needed in order to host a wh-moved phrase other than the subject. This section will investigate some of the predictions that follow from this difference for three well-studied empirical domains. The first two domains concerns two well-known asymmetries found in English between subjects, on the one hand, and object and adjuncts, on the other: do-support and wh-extraction from finite that-clauses. The third domain concern Zwart's (1997) finding that Dutch subject-initial sentences differ from all other sentences in that they are TPs, and not CPs.

\footnotetext{
${ }^{7}$ A potential alternative analysis, which in my view is the more plausible one for the transitive expletive construction in Dutch, is that the subject simply remains in it base position (SpecVP) and is assigned nominative case under Agree, and that the expletive is placed in SpecTP. This analysis does not seem suitable for Icelandic, however, given that this language differs from Dutch in that it cannot have expletives in embedded transitive clauses; see Vikner (1995: section 6.4) for a review of the relevant data; for additional reasons to adopt the analysis in (21) for Icelandic, we refer to the discussion in Jonas and Bobaljik (1996) of their object shift examples in (22) and (23); for completeness' sake, I want to add that their Dutch example in (24) is much better without the expletive er and that their argument therefore cannot be extended to Dutch.
} 


\subsubsection{Do-support}

This subsection briefly discusses the asymmetry between subjects and objects/adjuncts with respect to do-support: the examples in (24) show that whereas wh-movement of the latter triggers do-support, wh-movement of the former does not.

(24) a. Who borrowed this book yesterday?

$\mathrm{a}^{\prime}$. *Who did borrow this book yesterday?

b. Which book did John borrow yesterday?

$\mathrm{b}^{\prime}$. *Which book John borrowed yesterday?

c. When did John borrow this book?

$\mathrm{c}^{\prime}$. *When John borrowed this book?

[subject]

[object]

[adjunct]

Under the FI-approach this asymmetry is not expected given that the three wh-questions do not differ in their functional structure: they are all CPs and there is no obvious reason why the C-position should be phonetically realized in (24b\&c), but not in (24a). Under the EPapproach, on the other hand, the constructions with and without do-support do differ in an obvious way, as was illustrated for wh-subject and wh-object questions in (18) and (23), repeated below as (25). The contrast follows if we assume that do-support is a reflex of the remerging of $\mathrm{T}$ needed for creating the operator position in $(24 \mathrm{~b} \& \mathrm{c})$; compare Pesetsky \& Torrego (2001), who likewise assume that movement of $\mathrm{T}$ requires that $\mathrm{T}$ have a phonetic realization.

(25) a. Wh-subject questions in the EP-approach:

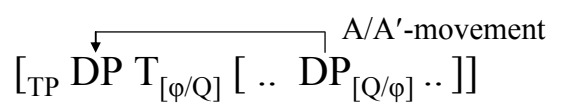

b. Wh-object questions in the EP-approach:

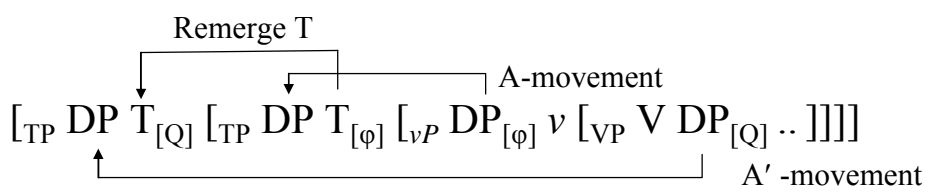

According to the EP-approach, the subject position in subject questions must be a position with mixed A- and A'-properties. This may perhaps provide us with new insights in the acceptability contrast between the two examples from West Ulster English in (26), which are taken from McCloskey (2000: p.72\&77) and which were put forward as evidence in favor of feature inheritance and parallel movement in Bošković (2012). For the sake of argument, I will simply follow McCloskey and Bošković in adopting the assumption that floating quantifiers are base-generated as part of the same DP as their associate noun phrase; see Doetjes (1997) and Bobaljik (2003) for arguments against this.

(26) a. Who was arrested [all $\left.t_{\mathrm{i}}\right]$ in Duke Street?

b. *They were arrested [all $t_{\mathrm{i}}$ ] last night.

Bošković claims that the acceptability contrast between the two examples in (26) can be accounted for by assuming (i) that quantifiers like all can be stranded by wh-movement but not by A-movement, and (ii) that wh-subjects are moved into SpecCP in one fell swoop, that is, without an intermediate movement step into SpecTP. This analysis raises the crucial question how the EPP property ("subject position must be filled") of West Ulster English is satisfied and Bošković argues that this shows that A- and $\mathrm{A}^{\prime}$-movement proceed in parallel fashion. This proposal runs into problems, however, due to the fact that the data in 
McCloskey (2000) show that West Ulster English behaves like Standard English with respect to do-support; we have seen that this runs afoul of postulating parallel movement.

The resulting paradox can perhaps be solved without the need to postulate parallel movement by assuming that stranding of the quantifier is licensed by the fact that SpecTP is a position with mixed A- and $\mathrm{A}^{\prime}$-properties in (26a), but not in (26b). Note that I do not necessarily commit myself to this alternative analysis because assumption (i), which Bošković incorrectly attributes to McCloskey, is problematic in light of the fact (not discussed in Bošković's article) that They were all arrested is fully acceptable in West Ulster English; see McCloskey (2000: p.76-7). The discussion just intends to show that assumption (i), if true at all, does not lead to the conclusion that feature inheritance and concomitant parallel movement are inescapable properties of core syntax.

\subsubsection{The ban on complementizer-trace configurations}

The second asymmetry between subjects and objects/adjuncts involves wh-extraction from embedded clauses: whereas wh-extraction of the latter is possible when the complementizer that is present, that must be absent when the former is extracted. This is again unexpected under the FI-, but expected under the EP-approach.

Consider the examples in (27): (27b) first shows that wh-extraction of direct objects is not sensitive to the presence or absence of the complementizer that, and $(27 \mathrm{c})$ shows that that passivization of embedded clauses is not sensitive to this either. Example (27d) shows, however, that wh-extraction of a derived subject (=internal argument) is impossible when the complementizer that is present.

(27) a. Mary said [(that) Bill read this book]

b. Which book did Mary say [(that) Bill read - ].

c. Mary said [(that) this book $\mathrm{i}_{\mathrm{i}}$ was read - by Peter].

d. Which book do you think [(*that $)$ — was read — by Peter].

The derivation of (27d) according to the FI-approach is given in (28), where the feature [F] on the embedded complementizer stands for whatever feature may be responsible for the intermediate $\mathrm{A}^{\prime}$-movement step. The issue that matters now is that the $\mathrm{A}$ - and the $\mathrm{A}^{\prime}$ movement within the embedded clause in (28) are both fully licit as is evidenced by the acceptability of $(27 \mathrm{~b} \& \mathrm{c})$. If these A- and $\mathrm{A}^{\prime}$-movement are really independent of each other, we wrongly predict that $(27 \mathrm{~d})$ is acceptable regardless of the absence or presence of the complementizer that.

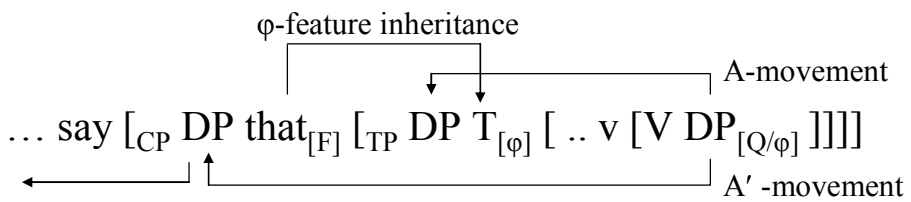

The EP-approach can make the correct predictions by appealing to economy considerations. In principle there are two derivations available: one in which the wh-subject is extracted directly from SpecTP, as in (29a), and one in which it is extracted via SpecCP, that is, via the specifier of an extended projection of T, as in (29b). 


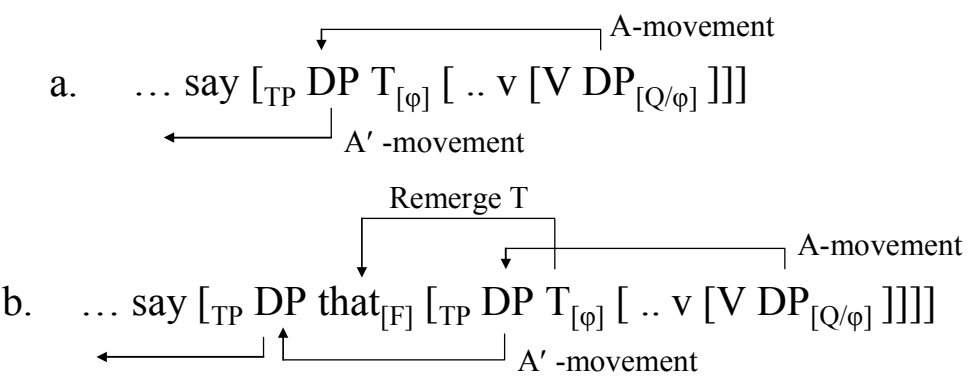

It will be clear that structure (29a) is preferred to (29b) in terms of costs as it involves two movement steps less: it does not require remerge of $\mathrm{T}$ and no intermediate $\mathrm{A}^{\prime}$-movement steps into the extended projection of T. ${ }^{8}$

\subsubsection{Dutch subject-initial sentences are TPs, not CPs}

The sentence-initial position in Dutch is special in that it normally cannot contain a weak (phonetically reduced) pronoun, which is illustrated in Table 1 by means of object pronouns.

Table 1: Sentence-initial object pronouns

\begin{tabular}{|l|l||l|l||}
\hline \multicolumn{2}{|l||}{} & SINGULAR & PLURAL \\
\hline \hline \multirow{2}{||l|}{$1^{\text {ST }}$ PERSON } & $\begin{array}{l}\text { Mij/*Me heeft Peter niet gezien. } \\
\text { 'Peter didn't see ME.' }\end{array}$ & $\begin{array}{l}\text { Ons heeft Peter niet gezien. } \\
\text { 'Peter didn't see US.' }\end{array}$ \\
\hline $2^{\text {ND }}$ PERSON & $\begin{array}{l}\text { Jou/*Je heeft Peter niet gezien. } \\
\text { 'Peter didn't see YOU.' }\end{array}$ & $\begin{array}{l}\text { Jullie/*Je heeft Peter niet gezien. } \\
\text { 'Peter didn't see YOU.' }\end{array}$ \\
\hline \multirow{2}{*}{$\begin{array}{l}3^{\mathrm{RD}} \\
\text { PERS } \\
\text { ON }\end{array}$} & MASCULINE & $\begin{array}{l}\text { Hem/*'m heeft Peter niet gezien. } \\
\text { 'Peter didn't see HIM.' }\end{array}$ & $\begin{array}{l}\text { Hun/*Ze heeft Peter niet gezien. } \\
\text { 'Peter didn't see THEM.' }\end{array}$ \\
\cline { 2 - 3 } & FEMININE & $\begin{array}{l}\text { Haar/*'r heeft Peter niet gezien. } \\
\text { 'Peter didn't see HER.' }\end{array}$ & \\
\cline { 2 - 3 } & NEUTER & $\begin{array}{l}\text { Dit/*'t heeft Peter niet gezien. } \\
\text { 'Peter didn't see IT/THIS.' }\end{array}$ & \\
\hline
\end{tabular}

There is, however, one notable exception to this general ban on weak pronouns in sentenceinitial position; weak subject pronouns can occur in this position (with the exception of the third-person singular masculine form -ie, which is enclitic and always follows the finite verb -or complementizer- in second position, and the second-person plural pronoun, which simply lacks a weak subject form in most varieties of Dutch).

\footnotetext{
${ }^{8}$ For concreteness' sake, the discussion in the main text has adopted Pesetsky \& Torrego's (2001) claim that the complementizer that is the spell-out of remerged $\mathrm{T}$, but this raises the following problem for the EP-approach: Why do languages like Dutch and German require the complementizer to be present in embedded clauses? It must be noted, however, that we could get the same result when we do have a lexical complementizer that and the CP-level is just the result of merge, given that subject extraction from CP involves an additional A'movement step. This will also give the right result for Dutch and German, given that there is reason to assume that these languages are just like Italian in allowing extraction only when the subject is extracted directly from its $v P$-internal position. I will not digress on this for reasons of space; see Broekhuis (1992:129ff.) for discussion.
} 
Table 2: Sentence-initial subject pronouns

\begin{tabular}{|c|c|c|c|}
\hline & SINGULAR & PLURAL \\
\hline \multicolumn{2}{|c|}{$1^{\mathrm{ST}}$ PERSON } & IIk/'k ben ziek. 'I am ill.' & Wij/We zijn ziek. 'We are ill.' \\
\hline \multicolumn{2}{|c|}{$2^{\mathrm{ND}}$ PERSON } & Jij/Je bent ziek. 'You are ill.' & Jullie ${ }^{\circ \circ} J e$ zijn ziek. 'You are ill.' \\
\hline \multirow{3}{*}{$\begin{array}{l}3^{\mathrm{RD}} \\
\text { PERS } \\
\text { ON }\end{array}$} & MASCULINE & Hij/*-ie is ziek. 'He is ill.' & \multirow[t]{3}{*}{ Zij/Ze zijn ziek. 'They are ill.' } \\
\hline & FEMININE & Zij/Ze is ziek. 'She is ill.' & \\
\hline & NEUTER & Het/'t is ziek. 'It is ill.' & \\
\hline
\end{tabular}

Zwart argued (1997) on the basis of this difference between subject and object pronouns (as well as other empirical phenomena) that, contrary to what was traditionally assumed, sentence-initial subjects are not topicalized but rather occupy the regular subject position in SpecTP. In other words, subject-initial main clauses differ from all other types of Dutch main clauses in that they are TPs, not CPs. This conclusion is fully compatible with the EP-, but not with the FI-approach.

\section{Optimization/economy considerations}

The previous sections discussed some empirical and conceptual consequences of the FI- and the EP-approach to feature sharing by $\mathrm{C}$ en $\mathrm{T}$, and concluded that the latter is to be preferred on both counts. This section concludes with a number of considerations in favor of the EPapproach that involve economy of derivations.

\subsection{Wh-movement is not triggered by formal features}

The discussion so far has simply followed the current practice in mainstream minimalism by assuming that $\mathrm{A}$ - and $\mathrm{A}^{\prime}$-movement are both triggered by formal features on some probe. However, it is not at all evident that this also holds for $\mathrm{A}^{\prime}$-movement. For example, Chomsky (1995:ch.3) assumes that wh-movement is universally overt on the bases of the discussion of wh-in-situ in Watanabe (1991), which convincingly shows that apparent wh-in-situ languages in fact involve movement of some phonetically empty question operator. The presumed universality of overt wh-movement makes it very unlikely that wh-movement is triggered by some formal feature on some functional head, given that the lexical specification of functional heads must be acquired by the language learner on the basis of the primary linguistic data, and is thus expected to exhibit at least a certain amount of cross-linguistic variation. If overt wh-movement is indeed universal, it is rather expected to be forced by some bare output condition imposed by the conceptual-intentional system.

\subsection{Full Interpretation}

The conclusion that overt wh-movement is universal, in fact, brings us back to the early interpretation of Full Interpretation. Chomsky (1991:440) suggested that there are only five syntactic objects that are legible and hence legitimate at LF: (i) arguments, (ii) adjuncts, (iii) lexical elements, (iv) predicates, and (v) operator-variable chains, which are claimed to consist of an operator in an $\mathrm{A}^{\prime}$-position and a variable in an A-position. That operators head non-trivial chains seems to follow from the fact that we are dealing with scope-taking elements. This has, in fact, been recognized by many researchers during the last three decades, and motivated, e.g., the wh-criterion (cf. May 1985 and Rizzi 1996) and OTconstraints like Grimshaw's (1997) OPERATOR IN SPECIFIER (OP-SPEC). Later research has further suggested that $\mathrm{A}^{\prime}$-movement is also required for semantic reasons for negation (e.g. Haegeman 1995 and Christensen 2005), quantified expressions (Jónsson 1996 and Svenonius 2000), and focus and topic constructions (Neeleman \& Van de Koot 2008). A language where we can readily detect all these movements is Hungarian; see the first six chapters in É. Kiss (2002). We illustrate this for topic and focus movement in the Hungarian examples in (30); 
example (30a) is normally considered the neutral order but involves a subject in topic position; example (30b) is a focus construction in which the object is moved in the preverbal focus position; (30c) differs from (30b) in that the subject is again presented as a topic. I have used small caps in order to indicate focus accent.

(30) a. János szereti Mari-t.

János loves Mari-ACC

[neutral/topic]

b. MARIT szereti János

[focus]

Mari-ACC János János

'It is Mari that János loves.'

c. János MARIT szereti

[topic + focus $]$

János Mari-ACC János

'As for János, it is Mari that he loves.'

Although it is not always easy to detect the $\mathrm{A}^{\prime}$-movements in question, it is likely that they apply overtly in all languages. Haegeman (1995), for example, extensively motivates this for movement of negative noun phrases in Dutch, which can be shown to be obligatory despite the fact that this cannot be demonstrated for direct or prepositional objects. The core of the argument is as follows: the fact that the PP op niemand cannot occupy its presumed postadjectival base position in examples like (31) shows that negative phrases must obligatorily be moved in some designated position (SpecNegP). I refer to Broekhuis \& Klooster (2010) for a more careful discussion of negation-movement in Dutch and English.

(31) a. dat Jan boos op Marie/*niemand is.

that Jan angry at Marie/no.one is

b. dat Jan op Marie/niemand boos is.

that Jan at Marie/no.one angry is

\subsection{Optimization: *Move and *Merge}

The conclusion that $\mathrm{A}^{\prime}$-movement is normally overt and needed for semantic reasons makes a formal feature approach to such movements quite a desperate undertaking. It seems much simpler to freely allow the computational system to create syntactic configurations, from which the conceptual-intentional system simply selects the most appropriate candidates in order to express certain meanings in, e.g., an optimality-theoretic fashion. Assuming for a moment that the application of $\mathrm{A}^{\prime}$-movement is a language-specific matter, our earlier claim that subject-initial clauses are not CPs but TPs can be made to follow from constraints like Grimshaw's OP-SPEC in tandem with independently motivated constraints like *MOVE (do not apply internal merge) and *MERGE (do not apply external merge); see, e.g., Grimshaw (1997), Dekkers (1999), and Broekhuis (2008). Under Grimshaw's original formulation of OP-SPEC (syntactic operators must be in specifier position), ranking (32a) states that it suffices to place a wh-subject in SpecTP, which predicts that even subject questions are not CPs, which can be supported by the fact that wh-subjects do not involve do-support; cf. Section 4.2.1. And (32b) states that CPs only arise when needed to create an operator-variable chain-unless, of course, their presence is motivated by other constraints like Pesetsky's (1997/1998) LE(CP).

(32) a. OP-SPEC $>>*$ MOVE

b. OP-SPEC $>>*$ MERGE

Assuming that wh-movement is universally needed in order to create an operator variable chain does not change much when it comes to the CP- or TP-status of the sentence, given that the constraint * MOVE would still block any movement into SpecCP that does not create an operator-variable chain, and *MERGE would still block CPs when they are not needed to 
create an operator-variable chain (again leaving aside the effects of other constraints like $\mathrm{LE}(\mathrm{CP})$ ). For subject-initial sentences, this means that CP-structures are normally harmonically bounded by TP-structures due to the fact that they invoke additional violations of *MOVE and *MERGE. Observe that the optimization procedures suggested in this subsection are no more than OT-formalizations of the economy conditions assumed in Chomsky's minimalist program that block unforced applications of internal and external merge.

\section{Conclusion}

The previous sections have compared Chomsky's (2008) Feature Inheritance-approach to a version of Grimshaw's (1997) Extended Projection-approach. I have shown that the empirical evidence that has been given as a motivation for the FI-approach is somewhat suspect and discussed a number of other empirical phenomena that are problematic for this approach but can be readily derived from the competing EP-approach. We concluded with a discussion of Full Interpretation that led to the conclusion that $\mathrm{A}^{\prime}$-movement is not triggered by formal features but forced by bare output conditions imposed by the conceptual-intentional system. If true, this would deal a death to the FI-approach, given that this results in the postulation of phase heads that have to pass on all their unvalued formal features to the next non-phase head. The EP-approach, on the other hand, is not affected by the elimination of such formal features given that we can simply allow the computational system to freely remerge the lexical/functional heads in order to create syntactic configurations that can be semantically interpreted by the conceptual-intentional system; the optimization procedure will then select the minimal structure that is legible by this system. This article thus contributes to the minimalist goal of current linguistic theory by purging the computational system of the unneeded operation of feature inheritance by showing that it should be replaced by the independently needed operation of remerge (=internal merge). 


\section{References}

Ackema, Peter, Ad Neeleman \& Fred Weerman. 1992. Deriving Functional Projections. In Proceedings of the North East Linguistic Society 23, ed. Amy J. Schafer, 17-31: University of Ottawa.

Bobaljik, Jonathan David. 2003. Floating Quantifiers: handle with care. In The second Glot International state-of-the-article book. The latest in Linguistics, eds. Lisa Cheng \& Rint Sybesma, 107-148. Berlin/New York: Mouton de Gruyter.

Bošković, Željko. 2012. Don't feed your movements when you shift your objects. In Ways of structure building, eds. Myriam Uribe-Etxebarria \& Vidal Valmala, 245-252. Oxford/New York: Oxford University Press.

Broekhuis, Hans. 1991. Chain-government. The Linguistic Review 6:297-374.

Broekhuis, Hans. 1992. Chain-government: issues in Dutch syntax, University of Amsterdam/HIL: PhD thesis.

Broekhuis, Hans. 2000. Against feature strength: the case of Scandinavian object shift. Natural Language and Linguistic Theory 18:673-721.

Broekhuis, Hans. 2005. Extraction from subjects: some remarks on Chomsky's On Phases. In Organizing grammar. Linguistic studies in honor of Henk van Riemsdijk, eds. Hans Broekhuis, Norbert Corver, Riny Huybregts, Ursula Kleinhenz \& Jan Koster. Berlin/New York: Mouton de Gruyter.

Broekhuis, Hans. 2007. Subject shift and object shift. Journal of Comparative Germanic Linguistics 10:109-141.

Broekhuis, Hans. 2008. Derivations and evaluations: object shift in the Germanic languages. Berlin/New York: Mouton de Gruyter.

Broekhuis, Hans \& Evelien Keizer. 2012. Syntax of Dutch, nouns and noun phrases, volume 1. Amsterdam: Amsterdam University Press.

Broekhuis, Hans \& Wim Klooster. 2010. Merge and Move as costly operations. Revista Virtual de Estudos da Linguagem 8 (theme issue on Optimality Theoretic Syntax edited by Gabriel de Avila Othero \& Sergio de Moura Menuzzi):155-182. www.revel.inf.br/.

Chomsky, Noam. 1986. Barriers. Cambridge, Mass.: MIT Press.

Chomsky, Noam. 1991. Some notes on economy of derivation and representation. In Principles and parameters in comparative syntax, ed. Robert Freidin. Cambridge, MA: MIT Press.

Chomsky, Noam. 1995. The minimalist program. Cambridge, MA: MIT Press.

Chomsky, Noam. 2000. Minimalist inquiries: the framework. In Step by step. Essays on minimalist syntax in honor of Howard Lasnik, eds. Roger Martin, David Michaels \& Juan Uriagereka, 89-155. Cambridge, MA: MIT Press.

Chomsky, Noam. 2001. Derivation by phase. In Ken Hale. A life in Language, ed. Michael Kenstowicz, 1-52. Cambridge, MA: MIT Press.

Chomsky, Noam. 2008. On phases. In Foundational Issues in Linguistic Theory. Essays in Honor of Jean-Roger Vergnaud, eds. Robert Freidin, Carlos P. Otero \& Maria Luisa Zubizarreta, 133-166. Cambridge, MA/Oxford: MIT Press.

Christensen, Ken Ramshøj. 2005. Interfaces. Negation - syntax - brain, University of Aarhus: $\mathrm{PhD}$ thesis.

De Hoop, Helen. 1992. Case configuration and noun phrase interpretation, University of Groningen: $\mathrm{PhD}$ thesis.

Dekkers, Joost. 1999. Derivations \& evaluations. On the syntax of subjects and complementizers, University of Amsterdam/HIL: PhD thesis. 
Den Besten, Hans. 1983. On the interaction of root transformations and lexical deletive rules. In On the formal nature of the Westgermania, ed. Werner Abraham, 47-131. Amsterdam: Benjamins. [Also appeared in: Den Besten (1989), Studies in West Germanic Syntax, PhD dissertation, Katholieke Universiteit Brabant. Amsterdam: Rodopi (chapter 1)].

Den Besten, Hans. 1985. The ergative hypothesis and free word order in Dutch and German. In Studies in German Grammar, ed. Jindřich Toman, 23-65. Dordrecht/Cinnaminson: Foris. [Also appeared in: Den Besten (1989), Studies in West Germanic Syntax, PhD dissertation, Katholieke Universiteit Brabant. Amsterdam: Rodopi (chapter 5)].

Den Dikken, Marcel. 2012. On feature interpretability and inheritance. Ms. City University of New York.

Den Dikken, Marcel \& Jeroen Van Craenenbroeck. 2006. Ellipsis and EPP repair. Linguistic Inquiry 37:653-664.

Doetjes, Jenny. 1997. Quantifiers and selection: on the distribution of quantifying expressions in French, Dutch and English, University of Leiden: $\mathrm{PhD}$ thesis.

É. Kiss, Katalin. 2002. The syntax of Hungarian. Cambridge (UK): Cambridge University Press.

Grimshaw, Jane. 1997. Projection, heads and optimality. Linguistic Inquiry 28:373-422.

Haegeman, Liliane. 1995. The syntax of negation. Cambridge: Cambridge University Press.

Haider, Hubert \& Martin Prinzhorn (eds.) 1989. Verb-second phenomena in Germanic languages. Dordrecht/Riverton: Foris Publications.

Holmberg, Anders \& Christer Platzack. 1995. The role of inflection in Scandinavian syntax. New York/Oxford: Oxford University Press.

Jonas, Dianne \& Jonathan Bobaljik. 1993. Specs for Subjects; the Role of TP in Icelandic. In Papers on Case and Agreement I. MIT Working Papers in Linguistics 18, eds. Jonathan Bobaljik \& Colin Phillips, 59-98. Cambridge (USA): MIT.

Jonas, Dianne \& Jonathan David Bobaljik. 1996. Subject positions and the roles of TP. Linguistic Inquiry 27:195-236.

Jónsson, Jóhannes G. 1996. Clausal architecture and case in Icelandic, GLSA: University of Massachusetts: PhD thesis.

Kayne, Richard S. 1994. The antisymmetry of syntax. Cambridge, MA: MIT Press.

Koster, Jan. 1978. Locality principles in syntax. Dordrecht: Foris.

Lenerz, Jürgen. 1977. Zur Abfolge nominaler Satzglieder im Deutschen. Studien zur deutschen Grammatik 5. Tübingen: Narr.

May, Robert. 1985. Logical form: its structure and derivation. Cambridge, MA: MIT Press.

McCloskey, James. 2000. Quantifier Float and wh-movement in an Irisch English. Linguistic Inquiry 31:57-84.

Nash, Léa \& Alain Rouveret. 1997. Proxy categories in phrase structure theory. NELS 27:287-304.

Neeleman, Ad \& Hans Van de Koot. 2008. Dutch scrambling and the nature of discourse templates. The Journal of Comparative Germanic Linguistics 11:137-189.

Pesetsky, David. 1997. Optimality theory and syntax: movement and pronunciation. In Optimality theory, eds. Diana Archangeli \& Terence Langendoen. Malden/Oxford: Blackwell.

Pesetsky, David. 1998. Some optimality principles of sentence pronunciation. In Is the best good enough?, eds. Pilar Barbosa, Danny Fox, Paul Hagstrom, Martha McGinnis \& David Pesetsky, 337-383. Cambridge, MA/London: MIT Press/MITWPL.

Pesetsky, David \& Esther Torrego. 2001. T-to-C movement: causes and consequences. In Ken Hale, A life in language, ed. Michael Kenstowicz, 355-426. Cambridge, MA/London: MIT Press. 
Richards, Marc D. 2007. On feature Inheritance: an argument from the Phase Impenetrability Condition. Linguistic Inquiry 38:563-572.

Rizzi, Luigi. 1996. Residual Verb-second and the wh Criterion. In Parameters and functional heads. Essays in comparative syntax, eds. Adriana Belletti \& Luigi Rizzi, 63-90. Oxford/New York: Oxford University Press.

Svenonius, Peter. 2000. Quantifier Movement in Icelandic. In The derivation of VO and OV, ed. Peter Svenonius, 255-292. Amsterdam: John Benjamins.

Vikner, Sten. 1995. Verb movement and expletive subjects in the Germanic languages: Oxford University Press.

Watanabe, Akira. 1991. Wh-in situ, subjacency and chain-formation, MIT: PhD thesis.

Zwart, Jan-Wouter. 1997. Morphosyntax of verb movement. A minimalist approach to the syntax of Dutch. Dordrecht: Kluwer Academic Publishers.

Zwart, Jan-Wouter. 2011. The syntax of Dutch. Cambridge: Cambridge University Press. 